\title{
Rosyjskie piśmiennictwo XIX wieku w zbiorach Biblioteki Uniwersyteckiej w Warszawie
}

Biblioteka Uniwersytecka w Warszawie powstała w 1817 r. i mimo burzliwych dziejów, na które składają się między innymi konfiskaty znacznej części księgozbioru, przemieszczenia i straty podczas obu wojen światowych, przetrwała do dnia dzisiejszego. Niezwykłe zasługi dla stworzenia jej księgozbioru położył Samuel Bogumił Linde, właściwy twórca biblioteki i jej dyrektor w latach 1817-1836. Instytucja założona w pierwszym okresie konstytucyjnego Królestwa Polskiego, na fali nadziei na pomyślny rozwój polskiego życia narodowego pod berłem Romanowów, dzieliła dalsze dramatyczne losy narodu. W 1817 r. otrzymała nazwę Biblioteki Publicznej i nie weszła w strukturę powstającego uniwersytetu, chociaż od początku stanowiła dla niego warsztat naukowy i zaplecze dydaktyczne. Po upadku powstania listopadowego, w przeciwieństwie do uniwersytetu, przetrwała represje reżimu Mikołaja I, chociaż około 70\% księgozbioru zostało skonfiskowane i wywiezione do Petersburga. Od tego czasu nosiła nazwę Biblioteki Rządowej (w latach 1834-1840). Wkrótce po utworzeniu Warszawskiego Okręgu Naukowego stała się jego biblioteką (1840-1862), by otrzymać miano Biblioteki Głównej Królestwa Polskiego w liberalnym okresie rządów Aleksandra II (tę funkcję pełniła w latach 1862-1871). W roku 1871 biblioteka została włączona w strukturę nowego Cesarskiego Uniwersytetu Warszawskiego, którego językiem wykładowym był rosyjski (do ewakuacji Rosjan w roku 1915). Dziewiętnastowieczny księgozbiór BUW narastał organicznie wraz z rozwojem instytucji, ukształtowany został przez różnorodne źródła wpływu, wśród których od 1819 r. niebagatelne znacznie miało prawo do otrzymywania egzemplarza obowiązkowego $\mathrm{z}$ terytorium Królestwa Polskiego ${ }^{1}$.

1 Zob. H. Kozerska, Warszawska Biblioteka Uniwersytecka w latach 1832-1871: Biblioteka Rządowa - Okręgu Naukowego - Glówna, Warszawa 1967. 
Zanim przejdziemy do właściwego tematu artykułu, winniśmy czytelnikowi kilka słów wyjaśnienia, co dokładnie rozumiemy pod pojęciem „księgozbiór dziewiętnastowieczny”. W polskim bibliotekarstwie istnieje ścisły podział na druki ,stare” - wydane do roku 1800 włącznie i „nowe”, czyli wszystkie wydane od roku 1801. Stare druki podlegaja szczególnej ochronie, są przechowywane i udostępnianie osobno, głównie do celów badawczych. Druki nowe przechowywane są w ogólnych magazynach, udostępniane są także na ogólnych zasadach. Dochodzi w ten sposób do paradoksu, że książka stu-, a nawet dwustuletnia jest uważana za „druk nowy”. Biblioteka Uniwersytecka w Warszawie w celu usunięcia tej sprzeczności wprowadziła w roku 1999 kategorię ,zbiory XIX wieku", którym nadano status historycznych zbiorów specjalnych. Zaliczono do niej książki i czasopisma z lat 1801-1918, przyjmując koncepcję tzw. „długiego dziewiętnastego wieku”. Tak zdefiniowane zbiory liczą w BUW około 600000 jednostek magazynowych. Za każdym razem, kiedy będzie mowa o zbiorach lub drukach dziewiętnastowiecznych, rozumieć będziemy pod tym pojęciem również pozycje z początku wieku XX, do roku 1918.

Nawet pobieżna znajomość dziewiętnastowiecznego księgozbioru BUW prowadzi do wniosku, że wydawnictwa rosyjskie stanowią jego istotną część. W publikacjach naukowych wyrażano niejednokrotnie opinię, że BUW specjalizuje się w literaturze rosyjskiej tego okresu i że kolekcja ta jest największą w Europie (poza krajami byłego ZSRR)2. Powszechna opinia upatruje przyczyn tego stanu rzeczy w dziedzictwie okresu, gdy biblioteka była częścią uniwersytetu cesarskiego ${ }^{3}$. Pogląd na temat wielkość kolekcji rosyjskiej opiera się na praktycznej znajomości księgozbioru, jednak dotychczas nikt nie podjął się próby jego zweryfikowania. W referacie wygłoszonym podczas międzynarodowego seminarium „Polskie i rosyjskie dziedzictwo kulturowe w zbiorach bibliotecznych - perspektywy badań" w maju 2015 r. autor niniejszych słów po raz pierwszy podjął próbę oszacowania liczebności zbiorów rosyjskich. Zaprezentowane wyniki mają charakter wstępny, nie moga pretendować do pełnej ścisłości, niemniej pozwalają choć trochę przybliżyć się do stanu rzeczywistego. Z całą pewnością w toku dalszych prac będą uściślone.

\footnotetext{
2 M. Cubrzyńska-Leonarczyk, Germanika w zbiorach Biblioteki Uniwersyteckiej w Warszawie, „Z Badań nad Polskimi Księgozbiorami Historycznymi”, t. 18, Warszawa 1997, s. 150.

3 O. Błażejewicz, Dzieje Biblioteki Uniwersyteckiej w Warszawie 1871-1915, Warszawa 1990, s. 59-60.
} 
Badanie częstotliwości występowania poszczególnych języków w zbiorach dziewiętnastowiecznych przeprowadzono na podstawie Katalogu Alfabetycznego Książek. Rejestruje on wszystkie druki zwarte wydane od 1801 roku, które wpłynęły do BUW do roku 1997. Rejestruje on zatem także dużą liczbę pozycji XX w., tj. wydanych po 1918 r. Badanie polegało na przejrzeniu co 25 skrzynki katalogowej, wyselekcjonowaniu w niej głównych kart odnoszących się do druków XIX w. i określeniu języka, w jakim zostały wydane. Badanie miało na celu oszacowanie posiadanej przez BUW liczby tytułów (nie egzemplarzy) w poszczególnych językach. Pod uwagę brany był tylko język publikacji, w związku z tym dzieła napisane i opublikowane na terytorium Rosji np. po francusku zostały zarejestrowane po prostu jako francuskie.

Z przeprowadzonych szacunków wynika, że zdecydowanie pierwszeństwo wśród tytułów druków zwartych dziewiętnastego wieku mają publikacje wydane po niemiecku, następnie w podobnych proporcjach występują tytuły w języku polskim, francuskim i rosyjskim, natomiast publikacje w języku angielskim i po łacinie są reprezentowane znacznie skromniej. Według tego szacunkowego badania książka rosyjska stanowi 18\% zbiorów, ale trzeba doliczyć tu druki wydane na terytorium cesarstwa w innych językach niż rosyjski. Bezpiecznie założyć można, że wówczas odsetek pozycji rosyjskich przekroczy $20 \%$.

Nieco dokładniejsze są szacunki dotyczące liczby rosyjskich tytułów wydawnictw ciagłych, w tym wypadku możliwe było przejrzenie całego katalogu czasopism i wydawnictw seryjnych. Przyjęto, że za czasopismo dziewiętnastowieczne uważa się takie, którego chociaż jeden numer ukazał się w okresie od 1 stycznia 1801 do 31 grudnia 1918 roku. W badaniu tym uwzględniono tylko pierwszy tytuł, liczono go łącznie ze wszystkim późniejszymi zmianami. Zarejestrowano 11501 dziewiętnastowiecznych tytułów wydawnictw ciagłych, z tego 2682 (23\%) stanowią tytuły wydane na terytorium Rosji w języku rosyjskim, 45 wydawnictwa ukazujące się poza terytorium imperium rosyjskiego $\mathrm{w}$ języku rosyjskim lub $\mathrm{w}$ innym języku, ale poświęcone w całości tematyce rosyjskiej. Największą trudność sprawia zaklasyfikowanie tytułów ukazujących się na ówczesnym terytorium Rosji, ale w innych niż rosyjski językach. W przypadku czasopism wydawanych przez instytucje naukowe rosyjskie np. po francusku z całą pewnością należy je zaliczyć do kategorii druków rosyjskich, jednak znacznie większą trudność sprawia zaklasyfikowanie tytułów wydawanych np. po niemiecku w guberniach bałtyckich, a zgodnie z polską tradycją bibliograficzną całkowicie wyłącza się z pojęcia wydawnictw rosyjskich tytuły wydawane po polsku na ziemiach należących wcześniej 
do Rzeczpospolitej. Trudno tutaj o przyjęcie jednoznacznego kryterium, dlatego też decyzję o ewentualnym zaliczeniu danego tytułu do puli rosyjskich wydawnictw ciagłych trzeba było podejmować indywidualnie dla każdej pozycji katalogowej. Takich tytułów zarejestrowano 200. Przy przyjęciu wyżej przedstawionych założeń liczba tytułów rosyjskich wydawnictw ciagłych XIX w. wzrasta do $25 \%$ całości zbioru.

Z przeprowadzonych szacunków wynika, że piśmiennictwo rosyjskie w dziewiętnastowiecznych zbiorach BUW stanowi 20-25\% całości zasobu. Obliczenia te mają oczywiście charakter wstępny, zwłaszcza w części dotyczącej druków zwartych. Precyzyjną odpowiedź na pytanie o liczbę publikacji rosyjskich da dopiero pełna retrokonwersja księgozbioru. Proces ten, niezwykle czasochłonny, mimo postępów poczynionych w ostatnich latach daleki jest jeszcze od zakończenia.

Kolekcja literatury rosyjskiej XIX wieku ukształtowana została przez wpływ bieżący biblioteki, nawarstwiała się w ciagu lat, a dopływ literatury rosyjskiej zależał między innymi od czynników politycznych. W potocznej opinii fundamentalne znaczenie dla wzrostu dziewiętnastowiecznego księgozbioru rosyjskiego ma okres po 1871 r., kiedy to biblioteka stała się częścią Cesarskiego Uniwersytetu Warszawskiego i po raz pierwszy w swoich dziejach znalazła się po zarządem Rosjan. Oczywiście nie można tego okresu lekceważyć, ale należy stwierdzić z całą odpowiedzialnością, że literaturę rosyjską gromadzono świadomie z dużą starannością już od początku istnienia instytucji. W zbiorach dziewiętnastowiecznych BUW bogato reprezentowana jest rosyjska produkcja wydawnicza także z pierwszej połowy wieku XIX. Musiała one napływać do biblioteki przed 1871 r., o czym świadczą własnościowe znaki biblioteczne. Każdy okres działalności biblioteki miał znaczenie dla ukształtowanie się kolekcji literatury dziewiętnastowiecznej.

Może najbardziej zaskakującym jest fakt, że podwaliny pod zbiór dziewiętnastowiecznych książek i czasopism rosyjskich położył S. B. Linde. Jego działalność w tym obszarze do niedawna była nieznana. Pierwsza próbą opisania jego działalności w tym zakresie był artykuł, który ukazał się w zborze artykułów z konferencji „Problemy Rosijsko-Polskoj istorii i kulturnyj dialog"'4. Oczywiście w czasach S. B. Lindego wśród pozycji gromadzonych w Bibliotece Publicznej przeważały publikacje wydane po łacinie, po polsku i w językach zachodnioeuropejskich. Znajomość

4 Z. Olczak, Деятельность Самуила Богумила Линде по доставке в варшавские библиотеки русских книг и журналов в конституционный период Царства Польского, [w:] Проблемы российско-польской истории и культурный диалог: материаль международной научной конференции, Новосибирск 2013, s. 480-486. 
języka i literatury rosyjskiej należała w oświeconych kręgach społeczeństwa polskiego zamieszkałego w Królestwie Polskim do rzadkości. S. B. Linde dostrzegał jednak potrzebę uzupełnienia zasobów Biblioteki Publicznej o publikacje rosyjskie. Dzięki zachowanej, niestety tylko częściowo, jego korespondencji z Bazylim Anastasewiczem ${ }^{5}$ możemy poznać poglądy dyrektora warszawskiej Biblioteki Publicznej na stosunki między Polakami i Rosjanami oraz zobaczyć jak od kuchni wyglądało sprowadzanie literatury rosyjskiej do Warszawy; jest to obraz daleki od sielanki. S. B. Linde uważał dobre zaopatrzenie biblioteki w publikacje rosyjskie za konieczność ze względu na ścisły związek polityczny, jaki połączył oba narody od chwili powołania do życia Królestwa Polskiego, złączonego z potężnym państwem rosyjskim osobą monarchy. W liście do B. Anastasewicza z 26 VI 1822 r. napisał, co następuje: „Radbym ja Panie bibliotekę naszą spanoszyć literaturą rosyjską i słowiańską tak jak ścisły związek między tymi krajami zachodzący tego wymaga; funduszu na to nie mam; trzeba szukać sposobów jak najłatwiejszych"6. Odczuwalny brak literatury rosyjskiej nie dotyczył tylko zbiorów Biblioteki Publicznej w Warszawie, lecz także innych ośrodków. W liście z dnia 30 VIII 1822 S. B. Linde relacjonował petersburskiemu przyjacielowi stan zbiorów bibliotecznych w głównym wówczas ośrodku mecenatu kultury polskiej - siedzibie książąt Czartoryskich w Puławach: „Lecz i tak uboga ona jest w rzeczy ruskie, w stosunku do innych gałęzi"'. Próbując zaradzić niedostatkowi literatury rosyjskiej, Linde rozwinął cały system wymiany, zakupu i pozyskiwania książek w drodze darów. Jego agentem księgarskim nad Newą stał się B. Anastasewicz.

Mając na uwadze powodzenie ulubionej idei zbliżenia polsko-rosyjskiego, do którego drogę widział przede wszystkim w - jakbyśmy to wyrazili dzisiaj - wymianie kulturalnej, S. B. Linde nie zawahał się nawet wystawić na szwank swej osobistej godności. Dnia 18 października 1822 r. pisał: „W wielkim ubóstwie naszym słowiańsko-rosyjskim nie wstydzę się nawet iść w dziady i puścić na żebraninę"8. S. B. Linde starał się uzyskać pomoc w dziele uzupełniania księgozbioru warszawskiej książnicy od Nikołaja Piotrowicza Rumiancowa, chciał uzyskać dublety

5 Bazyli Anastasewicz (1775-1845) uczony, popularyzator literatury polskiej w Rosji, urzędnik, sekretarz N. Rumiancowa.

6 Korespondencja Samuela Bogumiła Lindego z Bazylim Anastasewiczem 1822 1830, odczytał i opracował Marian Ptaszyk, Toruń 2013, s. 30. <http://kpbc.umk.pl/ dlibra/docmetadata? $\mathrm{id}=77379 \&$ from $=\&$ dirids $=1 \&$ ver $\_\mathrm{id}=\& 1 \mathrm{p}=1 \& \mathrm{QI}=\mathrm{BBCD} 5897 \mathrm{AF} 1$ FEBC7FDF88F25474EC718-6> (29 X 2015).

7 Tamże, s. 37.

8 Tamże, s. 48. 
z jego księgozbioru. Pisał w tej sprawie do B. Anastasewicza: „Gdyby JW. Rumiancow, który ma tyle dubletów, nie dał się nakłonić, by tym nas w chwalebnym zamiarze wspierał, co tam dla niego może być zawadą. Wreszcie byśmy tej części biblioteki, gdyby się zrobiła znakomita, nadali imię Rumiancowskiej, [...] Niechaj sława szanownego tego opiekuna nauk i w naszym kraju tak ściśle z Rosją związanym dokumentalnie zagruntuje się" . Prośbę o dublety ponawiał jeszcze dyrektor warszawskiej biblioteki później kilkukrotnie, obiecując sobie wiele po tak możnym mecenasie. Nawet - w istocie odmowną - odpowiedź Rumiancowa thumaczył sobie słowami: „Zatem nadzieja nie ze wszystkim stracona; osobliwie gdy mniemam, że zacny Kanclerz należy do liczby tych mężów, co mniej oświadczają a więcej świadcza" ${ }^{10}$. Ostatecznie nie udało się tą drogą uzupełnić „,ubogiego w rzeczy ruskie” księgozbioru Biblioteki Publicznej ${ }^{11}$.

S. B. Linde starał się oczywiście pozyskać wydawnictwa na inne sposoby, rozwinął także dzięki B. Anastasewiczowi cały system wymiany książek między Warszawą a Petersburgiem. Wymiana paczek i listów między tymi dwoma przyjaciółmi, w pełni podzielającymi poglądy na stosunki między narodami polskim i rosyjskim, odbywała się za pośrednictwem poczty urzędowej. Było to możliwe dzięki uprzejmości urzędników pracujących w kancelarii ministra sekretarza stanu w Petersburgu i w kancelariach urzędów warszawskich ${ }^{12}$. Korespondencja dotyczyła różnych spraw naukowych, okoliczności prac wydawniczych i badawczych, ale najważniejszym chyba tematem była wymiana książek. S. B. Linde posyłał B. Anastasewiczowi przede wszystkim polskie nowości wydawnicze; przesyłał także książki zakupione specjalnie w tym celu w Lipsku oraz książki przysłane przez uczonych, z którymi Linde z racji swych zainteresowań badawczych pozostawał w stałym kontakcie. B. Anastasewicz odwdzięczał się książkami rosyjskimi. Nawzajem prenumerowali na wymianę dla siebie czasopisma i wydawnictwa wielotomowe. S. B. Linde starał się prowadzić obrachunek z B. Anastasewiczem tak, żeby uniknąć przysyłania pieniędzy (co oczywiście nie zawsze było możliwe), ze względu na koszty operacji finansowych. Wymiana ta miała charakter osobisty. S. B. Linde nie występował tu jako dyrektor Biblioteki Publicznej, ale przede wszystkim - jako uczony. W wielu przypadkach nie jest jasne, czy zamawiana książka miała być przeznaczona do prywatnego

\footnotetext{
9 Tamże, s. 30.

10 Tamże, s. 60.

11 Tamże, s. 65.

12 Tamże, s. 5.
} 
użytku badacza, czy do zbiorów Biblioteki Publicznej. Zresztą według standardów epoki nie jest to rozróżnienie w pełni ścisłe. Bardzo zasłużony w dziele naukowego opracowania spuścizny S. B. Lindego Marian Ptaszyk przedstawił stosunek wybitnego uczonego do księgozbiorów publicznych, którymi zarządzał: ,niejednokrotnie, gdy Linde w swych pracach i listach pisał, że posiada jakąś książkę, nie oznaczało to, że miał ją w swoim własnym księgozbiorze, ale że znajdowała się ona w bibliotece której był zwierzchnikiem. Już od czasów pracy u Józefa Maksymiliana Ossolińskiego Linde miał zawsze bardzo łatwy dostęp do księgozbioru bibliotek, w których pracowal. [...] Stąd ów czasem bardzo osobisty sposób informowania o zbiorach niebędących jego prywatną własnością"13.

Jak wynika z przywoływanej już kilkukrotnie korespondencji z Bazylim Anastasewiczem, Lindemu zdarzało się pośredniczyć w wymianie literatury także między Warszawskim Towarzystwem Przyjaciół Nauk a Wolnym Towarzystwem Miłośników Literatury ${ }^{14}$.

S. B. Linde dążył do sprowadzenia do Warszawy i udostępnienia czytającej publiczności literatury rosyjskiej z własnej inicjatywy - nie znajdujemy w tej dążności inspiracji ze strony czynników rządowych. Co więcej, przynajmniej pośrednio taki wniosek można wyciagnąć z korespondencji Lindego, jego wysiłki spotykały się raczej z obojętnością w tych kręgach. Co warte odnotowania, sam Linde uważał swoje działania na rzecz zapełnienia księgozbiorów warszawskich książnic literaturą rosyjską za działalność patriotyczna, co z punktu widzenia standardów patriotyzmu polskiego drugiej połowy XIX wieku było już czymś niezrozumiałym. Sprowadzone $\mathrm{w}$ tym pierwszym okresie istnienia biblioteki publikacje rosyjskie siłą rzeczy nie były zbyt liczne.

Okres, który nastapił po upadku powstania listopadowego, był niezwykle trudny w dziejach biblioteki. Skonfiskowano ponad 70\% dotychczasowego księgozbioru (przed wybuchem powstania listopadowego liczył on 134 tys. woluminów). Biblioteka straciła miano publicznej, odtąd nazywano ją rządową. Na stanowisku dyrektora początkowo pozostał $\mathrm{S}$. B. Linde (do 1836 r.), liczba pracowników została ograniczona do trzech osób (od początku roku 1837). Nie dokonywano w tym okresie zakupów książek, jednak paradoksalnie następował szybki przyrost księgozbioru. W głównej mierze był on wynikiem przejmowania zbiorów bibliotecznych innych likwidowanych w tym czasie instytucji. Spośród tych zespołów największe znacznie dla kształtowania się kolekcji rosyjskiej miało

13 M. Ptaszyk, Z badań nad księgozbiorem prywatnym Samuela Bogumiła Lindego, „Roczniki Biblioteczne”, 52:2008, s. 87.

${ }^{14}$ Korespondencja S. B. Lindego..., s. 70. 
przejęcie przez Bibliotekę Rządową szczątków biblioteki Warszawskiego Towarzystwa Przyjaciół Nauk. Jego znakomite zbiory, chociaż ilościowo skromniejsze od zasobów Biblioteki Publicznej, miały ogromne znaczenie dla życia umysłowego Polski, gromadzone były niezwykle starannie z myślą o stworzeniu warsztatu pracy dla uczonych oraz dokumentowania całości polskiego dorobku piśmienniczego. Biblioteka WTPN została zamknięta, a zbiory skonfiskowane i wyselekcjonowane według tego samego klucza co zbiory Biblioteki Publicznej. W Warszawie pozostawiono około 7 tys. druków, które przeniesiono do pomieszczeń Biblioteki zwanej wówczas Rządową. W tym okresie wartym odnotowania czynnikiem, który miał znacznie dla przyrostu zbiorów rosyjskich, był wpływ książek z egzemplarza obowiązkowego. $Z$ tego źródła w drugiej połowie lat trzydziestych wpłynęło nieco podręczników do nauki j. rosyjskiego, co jest o tyle istotne, iż dokumentuje miejscową produkcję wydawniczą w języku rosyjskim ${ }^{15}$.

Wydarzeniem o dużej doniosłości dla dziejów Biblioteki Rządowej było powołanie w Królestwie Polskim Warszawskiego Okręgu Naukowego, podporządkowanego bezpośrednio ministrowi oświaty w Petersburgu. Fakt ten stanowił złamanie zasady autonomii administracyjnej, gwarantowanej postanowieniami statutu organicznego nadanego Królestwu przez cesarza Mikołaja I w roku 1832, i jako taki był uważany za kolejną represję caratu wobec Polaków. Ministrem oświaty był w owym czasie osławiony S. S. Uwarow, gorliwy wykonawca polityki oświatowej cara. Biblioteka Rządowa została w 1840 r. podporządkowana nowo utworzonemu okręgowi, zmieniono jej nazwę na Bibliotekę Warszawskiego Okręgu Naukowego. Paradoksalnie poprawiło to jej położenie materialne i pomogło ustabilizować działalność. Dzięki podporządkowaniu biblioteki okręgowi naukowemu po raz pierwszy od momentu likwidacji w Warszawie uniwersytetu pojawiają się środki na zakup książek, a przyrost księgozbioru zaczyna mieć charakter bardziej planowy i regularny, niż miało to miejsce w czasach biblioteki rządowej. Bezpośrednio po podporządkowaniu Biblioteki Warszawskiego Okręgowi Naukowemu, w roku 1840 dokonano zakupu 510 książek z nieznanych dziś źródeł księgarskich. Był to pierwszy od upadku powstania zakup, składały się nań wyłącznie książki rosyjskie z lat dwudziestych i trzydziestych XIX w. Wtedy też po raz pierwszy w okresie popowstaniowym wprowadzone zostają do zbiorów biblioteki dzieła Adama Mickiewicza - sonety w przekładzie na rosyjski Iwana Iwanowicza Kozłowa. W zbiorach po-

15 H. Kozerska, dz. cyt., s. 6. 
jawia się także almanach „Polarnaja Zwiezda”, wydawany przez Aleksandra Aleksandrowicza Bestużewa i Kondratija Fiodorowicza Rylejewa w latach 1823-1825 ${ }^{16}$. Od 1849 r. w budżecie Warszawskiego Okręgu Naukowego pojawia się stała pozycja na zakup książek zagranicznych w wysokości 1200 rubli rocznie. W okresie tym spośród nabywanych książek 30-50\% stanowiły publikacje rosyjskie, wprowadzono prenumeratę czasopism rosyjskich, takich tytułów jak „Otieczestweinnyje Zapiski”, „Sowremiennik”, nieco później „Russkoj Wiestnik”, „Russkaja Biesieda”, „Bibliograficzeskije Zapiski”. Księgozbiór rozwijał się również za pośrednictwem nabywania prywatnych bibliotek, które właściciele lub ich spadkobiercy pragnęli spieniężyć. Niektóre z nich stanowiły istotny dopływ publikacji rosyjskich. Tak miało to miejsce z księgozbiorem Nikołaja Iwanowicza Pawliszczewa, który w 1848 r., wedle wyrażenia historyka Biblioteki Uniwersyteckiej Heleny Kozerskiej ,wcisną”” 359 dzieł bibliotece, które uznał w swoim księgozbiorze za zbędne. Po 1850 r. nabyto księgozbiór generała Okuniewa, podobnie w 1855 r. zakupiono od spadkobierców prywatny księgozbiór S. B. Lindego, w którym na ogólną liczbę 1031 dzieł w 1502 tomach 138 dzieł w 246 tomach stanowiły książki rosyjskie ${ }^{17}$.

Omawiając dzieje kształtowania kolekcji literatury rosyjskiej w BUW, trzeba przede wszystkim zwrócić uwagę na „Dary Najjaśniejszego Pana". Nadesłane zostały z Petersburga w dwóch partiach w latach 1840-1842. O przekazaniu tak wielkiej liczby książek zadecydowało spotkanie S. S. Uwarowa z I. Paskiewiczem, który wystapił do monarchy z inicjatywą przekazania do warszawskiej biblioteki książek z zasobów petersburskich. Decyzja podjęta została bezpośrednio przez cesarza Mikołaja I. Zarówno w reskrypcie carskim, jak również w pismach ministra S. S. Uwarowa do kuratora Warszawskiego Okręgu Naukowego powtarza się motyw troski o zaopatrzenie bibliotek szkolnych $\mathrm{w}$ literaturę. Był to paradoks, gdyż właśnie z woli cesarza ogołocono ziemie Kongresówki ze zbiorów bibliotecznych. Pierwszy transport darów nadszedł do Biblioteki w październiku $1840 \mathrm{r}$. Wyprawiono go z Petersburga w 46 skrzyniach drogą morską do Gdańska, a stamtąd Wisłą do Warszawy. Składał się on z 6432 dzieł w 12455 woluminach, z tego 2591 dzieł w 3746 woluminach stanowiły książki w języku rosyjskim, a 3841 dzieł w 8709 woluminach - dzieła w językach zachodnioeuropejskich (po łacinie, niemiecku, francusku, angielsku). Druga partia

\footnotetext{
16 Tamże, s. 9-10.

17 Tamże, s. 12-13.
} 
książek nadeszła z Petersburga w r. 1842. Składała się ona z 2729 dzieł w 7507 woluminach, do tego dochodziło jeszcze 842 woluminów czasopism oraz 3 atlasy i 5 map. W tej liczbie 596 dzieł w 1214 woluminach stanowiły publikacje w języku rosyjskim ${ }^{18}$. Ówczesny bibliotekarz Paweł Zaorski w raporcie złożonym kuratorowi w dniu 18/30 listopada 1840 r. dał krótką wstępna charakterystykę daru: „Ile z ogółowego przy rozpakowaniu i zdawaniu ksiag przeglądania dostrzec można było, nadmienić należy, że ten zbiór ważnych źródłowych dzieł do rozmaitych przedmiotów mianowicie do historii, lingwistyki, prawa i poligrafii zawiera niemało". Znaczna liczba książek występowała w tym księgozbiorze w wielu egzemplarzach ${ }^{19}$.

W ten sposób imperator Mikołaj I dotrzymywał (przynajmniej we własnym mniemaniu) danego słowa, że „co uznam za stosowane moge później darować”. Jednak przekazane w ramach „Darów Najjaśniejszego Pana" książki nie stanowiły w żadnym przypadku rewindykacji skonfiskowanych wcześniej zbiorów polskich, chociaż część książek darowanych na poczatku lat czterdziestych była dekadę wcześniej wywieziona z ziem polskich, a nawet wśród ,darowanych” książek znalazła się pewna liczba załuscianów ${ }^{20}$. Oczywiście widać wyraźnie tendencję do „rusyfikacji” księgozbioru warszawskiej biblioteki, ale nie została ona tym razem zrealizowana konsekwentnie, większość „Darów” stanowią wszak dzieła w językach zachodnioeuropejskich. Książki nadesłane $\mathrm{w}$ ramach tej akcji zostały opisane w oddzielnych inwentarzach, które szczęśliwie zachowały się do dnia dzisiejszego, co wobec przemieszania księgozbioru naszej biblioteki i stosowania przez cały XIX wiek zasady nieustawiania książek według kolejności wpływu, lecz według klucza treściowego, daje nam współcześnie możliwość przeprowadzenia analizy zawartości tychże darów. Oczywiście dużą część spośród pozycji, które przekazane zostały wówczas naszej bibliotece, zaliczamy dziś do „starych druków”. Z zachowanych w Archiwum BUW inwentarzy tych darów wynika m.in. bardzo ciekawy fakt, iż książki rosyjskie były dobierane według innego klucza. O ile wydania w językach zachodnioeuropejskich stanowią w przeważającej części książki z XVII i XVIII, trochę także z XVI w., to praktycznie nie spotyka się wśród nich publikacji nowszych, z wieku XIX. W przypadku książek rosyjskich znako-

18 Tamże, s. 14.

19 Tamże, s. 15.

20 H. Juszczakowska, Z badań nad zaluscianami w Bibliotece Uniwersytetu Warszawskiego, „Z Badań nad Polskimi Księgozbiorami Historycznymi”, z. 2, Warszawa 1976, s. 46. 
mitą większość stanowią druki dziewiętnastowieczne, wyjątkowo tylko trafiają się pojedyncze druki z końca XVIII wieku ${ }^{21}$.

Wydarzeniami o szczególnej doniosłości dla kolekcji dziewiętnastowiecznej literatury w BUW w czasach, gdy stała się Biblioteką Główną Królestwa Polskiego, było pozyskanie za sprawą Aleksandra Wielopolskiego w roku 1863 dubletów z bibliotek petersburskich. Z tego źródła wpłynęło 17 tys. tomów z Cesarskiej Biblioteki Publicznej, Biblioteki Akademii Nauk i Biblioteki Sztabu Generalnego. W początkowym okresie istnienia Biblioteki Głównej zwrócono większą uwagę na gromadzenie literatury zachodnioeuropejskiej, zwłaszcza koniecznej do pracy naukowej i dydaktycznej pracowników Szkoły Głównej. W tym czasie ograniczona została prenumerata czasopism rosyjskich - pozostały tylko trzy tytuły: „Żurnał Ministerstwa Narodnowo Proswieszczenija”, „Izwiestija Imperatorskoj Akademii Nauk”, „Russkij Wiestnik”. Jednak już od połowy lat sześćdziesiątych, pod naciskiem czynników politycznych, znów szerszym strumieniem zaczynają napływać publikacje rosyjskie. Od 1865 r. udział książek rosyjskich w kupnie wzrasta aż do 40\%. W dalszym ciagu napływają książki z dubletów bibliotek Petersburga (Cesarskiej Akademii Nauk, Cesarskiej Akademii Sztuk). W tym okresie wpłynął także księgozbiór Rady Stanu Królestwa Polskiego, w tym znacząca liczba książek rosyjskich wydanych do lat trzydziestych XIX w. oraz księgozbiór Rady Wychowania, który wniósł pewną liczbę książek rosyjskich z pierwszej połowy XIX wieku ${ }^{22}$.

Po likwidacji Szkoły Głównej (1869) przyszła kolej na Bibliotekę Główna, która w 1871 r. utraciła niezależność instytucjonalną i została włączona do Cesarskiego Uniwersytetu Warszawskiego. Po raz pierwszy także jej kierownictwo znalazło się w rękach Rosjan. Na uzupełnianie księgozbioru wpływ odtąd miały przede wszystkim potrzeby dydaktyczne i naukowe uniwersytetu, w którym językiem wykładowym był rosyjski; swoje piętno odcisnęła także bieżąca polityka oświatowa caratu. Księgozbiór kształtowały takie źródła wpływu jak ożywiona wymiana z instytucjami w naukowymi w Cesarstwie, wpływ z egzemplarza obowiązkowego, co oznaczało także wzmożony dopływ miejscowych publikacji w języku rosyjskim. Gromadzono oczywiście literaturę naukową w języku rosyjskim, zwłaszcza z zakresu dyscyplin wykładanych na uniwersytecie, doniosłe znaczenie miało także gromadzenie produkcji wydawniczej

21 Warszawa, Archiwum BUW: Biblioteka Rządowa inwentarz za 1845. A - książki rosyjskie dar Cara nadesłany w 1840 sygn. I/19; Biblioteka Rządowa inwentarz za 1845. B - książki w obcych językach dar Cara nadesłany w 1840 sygn. I/20.

${ }^{22}$ H. Kozerska, dz. cyt., s. 67. 
własnego uniwersytetu, oczywiście w 100\% rosyjskojęzycznej. Niemałe znaczenie miał dopływ książek z darów profesorów i innych osób, wśród których na pierwszym miejscu wymienić oczywiście trzeba księgozbiór Arkadego A. Tołoczanowa, ale także dar prof. Iwana Wostokowa ${ }^{23}$.

Dziewiętnastowieczny księgozbiór rosyjski należący do Biblioteki Uniwersyteckiej w Warszawie jest z całą pewnością zbiorem znaczącym liczebnie, jest także intersujący dzięki temu, że ukształtowany został równolegle do dziejów instytucji, przyrastał wraz z jej rozwojem organicznie, niebagatelne znacznie dla jego rozwoju miał wpływ z egzemplarza obowiązkowego ograniczonego do terytorium Kongresówki. Miejscowa produkcja wydawnicza w języku rosyjskim być może z punktu widzenia badawczego przedstawia się w obecnej chwili jako najciekawszy obszar eksploracji.

Dziewiętnastowieczny księgozbiór rosyjski BUW ma charakter uniwersalny - gromadzi książki ze wszystkich dziedzin wiedzy, jest także niezwykle intersujący od strony proweniencyjnej, historia niejednej książki stanowi przyczynek do dziejów relacji polsko-rosyjskich w XIX stuleciu. Jest także niezwykle zróżnicowany od strony wydawniczej, mieści zarówno druki luksusowe, przeznaczone dla znawców bibliofilów, jak i druki o charakterze użytkowym - jak np. rozkłady jazdy kolei czy prospekty reklamowe. Znaleźć w nim możemy druki oficjalne, upamiętniające wydarzenia związane $\mathrm{z}$ rocznicami rosyjskiego domu panującego obok druków najsurowiej zakazanych przez cenzurę rządową jak np. londyńskie wydania „Wolnej Drukarni Rosyjskiej”, a także podziemne druki ugrupowań rewolucyjnych. Prawo do otrzymywania egzemplarza obowiązkowego miało szczególnie duże znaczenie dla gromadzenia druków, które przez współczesnych traktowane były jako małowartościowe, a dziś stanowią ważny dokument epoki. Do tej kategorii należy niemała część rosyjskojęzycznej produkcji wydawniczej Królestwa Polskiego. Jego pełne naukowe opracowanie wymagać będzie jeszcze wiele wysiłku i starań, konieczne są regularne badania proweniencyjne oraz kwerendy archiwalne krajowe i zagraniczne.

${ }^{23}$ Zob. O. Błażejewicz, dz. cyt., s. 77-78. 
Streszczenie

\section{Rosyjskie piśmiennictwo XIX wieku w zbiorach Biblioteki Uniwersyteckiej w Warszawie}

Biblioteka Uniwersytecka w Warszawie powstała w 1817 roku. Jej pierwszym dyrektorem został S. B. Linde, wybitny uczony slawista i leksykograf. Biblioteka mimo bardzo poważnego kryzysu wywołanego represjami politycznymi po upadku powstania listopadowego, kiedy skonfiskowano około $70 \%$ zbiorów, działa nieprzerwanie do dnia dzisiejszego. W ciagu swojej historii wielokrotnie zmieniała się jej afiliacja instytucjonalna i w związku z tym oficjalna nazwa, ale zachowana została ciagłość instytucjonalna. Była kolejno: Biblioteką Publiczna, związaną z Królewskim Uniwersytetem Warszawskim (1817-1834), Biblioteką Rządową (1834-1840), Biblioteką Warszawskiego Okręgu Naukowego (18401862), Biblioteką Główną (1862-1871), Biblioteką Cesarskiego Uniwersytetu Warszawskiego z rosyjskim językiem wykładowym (1871-1915), następnie Biblioteką Uniwersytecką.

Bogate zbiory dziewiętnastowieczne, które nawarstwiały się na przestrzeni dziejów biblioteki, spowodowały, że w roku 1999 wydzielono je i uznano za historyczne zbiory specjalne, przyjmując jako obowiązujące dla nich cezury lata 1801-1918. W tej kategorii zbiorów szczególnie wyróżnia się kolekcja literatury rosyjskiej, która w powszechnej opinii jest specjalnością BUW. W artykule zostały zaprezentowane wstępne wyniki badań, które miały na celu dokładniejsze określenie liczebności tej kolekcji. W sposób przeglądowy przedstawiono także etapy kształtowania się bogatych zbiorów rosyjskich, korygując niektóre rozpowszechnione opinie na ten temat.

Słowa kluczowe: Biblioteka Uniwersytecka w Warszawie - książka rosyjska w zbiorach polskich - historia księgozbiorów - książka XIX w.

\section{Summary}

\section{Russian nineteenth-century prints in the holdings of the Warsaw University Library}

The University Library in Warsaw was established in 1817, and Samuel B. Linde, an outstanding man of learning, Slavonic philologist, and lexicographer became its first director. The Library, in spite of the grave crisis caused by the political repressions after the fall of the November Uprising in 1831, when $70 \%$ of its holdings were confiscated, was not closed down and continued to function, and retains its institutional continuity until today. During its history, 
the Library's affiliation changed several times. The name of the Library also underwent changes: Public Library unofficially linked with the University of Warsaw (1817-1834); Government Library (1834-1840); Library of the Warsaw Educational District (1840-1862); Central Library (1862-1871); Library of the Imperial University of Warsaw (1871-1915); and finally, since 1915, the University Library in Warsaw.

Nineteenth-century holdings of the University Library are particularly abundant and valuable. In 1999, in acknowledgment of their importance, books published between 1801-1918 were separated from the rest of the holdings and assigned the status of a special historical collection. Within this category, the Russian publications are considered of exceptional importance. They are widely deemed the specialisation of the University Library in Warsaw. In his article Z. Olczak presents the results of a preliminary research aimed at a more precise estimation of the number of Russian publications in the Library. He also discusses the development of these holdings in historical context, and proposes amendments to widespread erroneous believes in this respect.

Keywords: Warsaw University Library - Russian printed books i Polish collections - history of book collections - nineteenth-century book. 